\title{
Use of Hypothermia to Allow Low-Tidal-Volume Ventilation in a Patient With ARDS
}

\author{
Melissa Duan MD, Lorenzo Berra MD, Asheesh Kumar MD, Susan Wilcox MD, \\ Steve Safford RRT, Robert Goulet MSc RRT, Michelle Lander RN, and Ulrich Schmidt MD PhD
}

\begin{abstract}
Low-tidal-volume ventilation reduces mortality in patients with ARDS, but there are often challenges in implementing lung-protective ventilation, such as acidosis from hypercapnia. In a patient with severe ARDS we achieved adequate ventilation with a very low tidal volume $(4 \mathrm{~mL} / \mathrm{kg}$ ideal body weight) by inducing mild hypothermia (body temperature $35-36^{\circ} \mathrm{C}$ ). Key words: acute respiratory distress syndrome; ARDS; mechanical ventilation; lung-protective ventilation; tidal volume; hypothermia; permissive hypercapnia. [Respir Care 2011;56(12):1956-1958. (C 2011 Daedalus Enterprises]
\end{abstract}

\section{Introduction}

ARDS is defined as an acute onset of severe respiratory distress with bilateral infiltrates on chest radiograph, an absence of left-atrial hypertension, a pulmonary capillary wedge pressure of $\leq 18 \mathrm{~mm} \mathrm{Hg}$, no clinical signs of left-heart failure, and severe hypoxemia $\left(\mathrm{P}_{\mathrm{aO}_{2}} / \mathrm{F}_{\mathrm{IO}_{2}} \leq 200\right.$ $\mathrm{mm} \mathrm{Hg}) .{ }^{1}$ The current standard practice for the management of ARDS includes lung-protective ventilation, which entails low tidal volume $\left(\mathrm{V}_{\mathrm{T}}\right)(6 \mathrm{~mL} / \mathrm{kg}$ ideal body weight), plateau pressure $\leq 30 \mathrm{~cm} \mathrm{H}_{2} \mathrm{O}$, and modest PEEP.

Low- $\mathrm{V}_{\mathrm{T}}$ ventilation is the only ventilation strategy that has been shown to reduce mortality in patients with ARDS. ${ }^{2}$ In the ARDS Network trial, ${ }^{2}$ patients were randomized to either low $\mathrm{V}_{\mathrm{T}}(\leq 6 \mathrm{~mL} / \mathrm{kg}$ predicted body weight) and plateau pressure $\leq 30 \mathrm{~cm} \mathrm{H}_{2} \mathrm{O}$ or conventional ventilation with higher $\mathrm{V}_{\mathrm{T}}$. Low $\mathrm{V}_{\mathrm{T}}$ had a $9 \%$ absolute reduction in

The authors are affiliated with the Surgical Intensive Care Unit, Department of Anesthesia, Critical Care, and Pain Medicine, Massachusetts General Hospital, Harvard Medical School, Boston, Massachusetts.

To avoid potential conflict of interest, Editor in Chief Dean Hess was blinded to the peer review process, deferring to Associate Editor Richard Branson.

The authors have disclosed no conflicts of interest.

Correspondence: Ulrich Schmidt MD PhD, Surgical Intensive Care Unit, Department of Anesthesia, Critical Care, and Pain Medicine, Massachusetts General Hospital, 55 Fruit Street, Gray 4, Boston MA 02114. Email: uschmidt@partners.org.

DOI: $10.4187 /$ respcare.01211 mortality risk, more ventilator-free hospital days, and more days free from nonpulmonary-organ failure. However, we do not know if further lowering $\mathrm{V}_{\mathrm{T}}$ or airway pressure would further improve survival.

In addition to lung-protective ventilation, many unproven strategies have been attempted to improve oxygenation in patients with severe ARDS, including alveolar recruitment, airway pressure-release ventilation, high-frequency oscillatory ventilation, and high-frequency percussive ventilation. Other strategies include paralysis (which recently was found to improve survival in early stages of ARDS, possibly by improving patient-ventilator synchrony and decreasing barotrauma and biotrauma), ${ }^{3}$ inhaled nitric oxide, inhaled prostacyclin (which improves ventilation-perfusion matching), extracorporeal membrane oxygenation, and positioning maneuvers such as prone position.

Barriers to the use of low- $\mathrm{V}_{\mathrm{T}}$ ventilation in patients with ARDS include hypercapnia and acidosis. We hypothesized that inducing hypothermia might allow very-low- $\mathrm{V}_{\mathrm{T}}$ ventilation by decreasing carbon dioxide production and thus decreasing respiratory acidosis. There have been case reports on hypothermia as an adjunct in treating patients with ARDS. One patient with ARDS and sepsis had improved oxygenation with hypothermia. ${ }^{4}$ Wetterberg and Steen reported the successful use of hypothermia and a buffer infusion in a patient with ARDS. ${ }^{5}$ However, neither of those patients underwent hypothermia in order to allow low- $\mathrm{V}_{\mathrm{T}}$ ventilation.

\section{Case Report}

A 29-year-old man was admitted to the intensive care unit after an aspiration event. He was intubated on arrival 


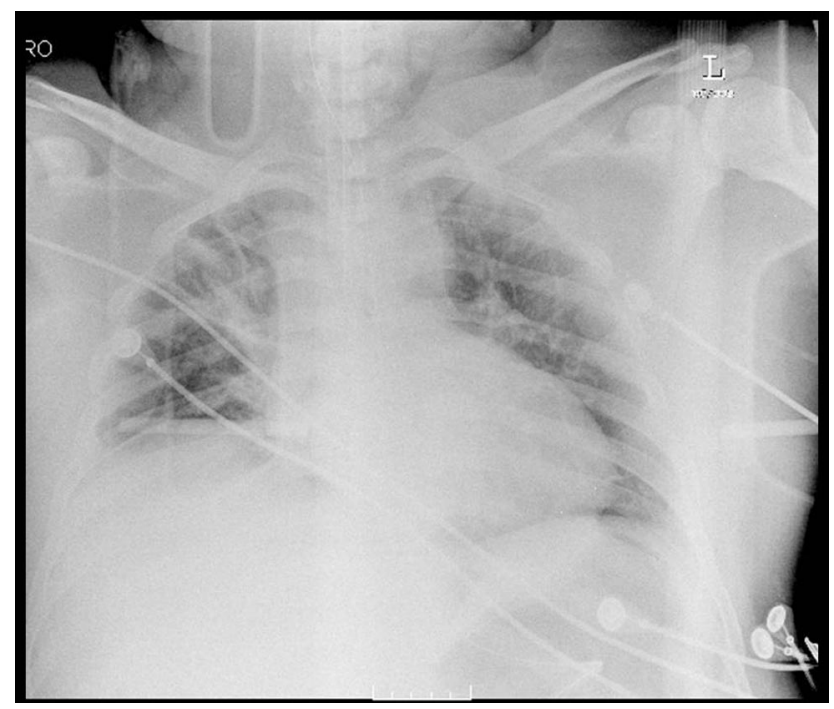

Fig. 1. Radiograph on admission day 3 is consistent with ARDS.

to the hospital. His arterial blood gases $(\mathrm{pH} 7.33$, $\mathrm{P}_{\mathrm{aCO}_{2}} 44 \mathrm{~mm} \mathrm{Hg}$, and $\mathrm{P}_{\mathrm{aO}_{2}} 109 \mathrm{~mm} \mathrm{Hg}$ on $100 \%$ oxygen) and chest radiograph (Fig. 1) were consistent with ARDS. His oxygenation continued to worsen, and he was paralyzed to improve patient-ventilator synchrony and to achieve lung-protective ventilation. His temperature rose to $38.4^{\circ} \mathrm{C}$ after he was admitted to the intensive care unit. $\mathrm{He}$ was actively cooled to $35-36^{\circ} \mathrm{C}$ in an effort to decrease carbon dioxide production. By achieving a temperature of $35-36^{\circ} \mathrm{C}$ we were able to decrease $\mathrm{V}_{\mathrm{T}}$ to $4 \mathrm{~mL} / \mathrm{kg}$ ideal body weight (Table 1 ). The other ventilator settings were held constant (PEEP $12 \mathrm{~cm} \mathrm{H}_{2} \mathrm{O}, \mathrm{F}_{\mathrm{IO}_{2}} 0.60$, respiratory rate 28 breaths $/ \mathrm{min}$ ). His hemodynamic variables were: blood pressure range 117-147/68-76 mm Hg, central venous pressure range $8-10 \mathrm{~mm} \mathrm{Hg}$, heart rate range $98-$ 108 beats/min. His plateau pressure dropped from $23 \mathrm{~cm} \mathrm{H} \mathrm{H}_{2} \mathrm{O}$ to $18 \mathrm{~cm} \mathrm{H}_{2} \mathrm{O}$ with low- $\mathrm{V}_{\mathrm{T}}$ ventilation. While there was an increase in his $\mathrm{P}_{\mathrm{aCO}}$, his $\mathrm{pH}$ remained stable despite the low $\mathrm{V}_{\mathrm{T}}$ (see Table 1). His $\mathrm{pH}$ and $\mathrm{P}_{\mathrm{aCO}}$ tolerated the $4 \mathrm{~mL} / \mathrm{kg} \mathrm{V}_{\mathrm{T}}$, and ventilator settings were maintained.
After 6 days of hypothermia we rewarmed the patient to evaluate for clinical improvement. Over the course of 8 hours his temperature increased from $35.9^{\circ} \mathrm{C}$ to $37.9^{\circ} \mathrm{C}$, $\mathrm{pH}$ decreased from 7.41 to 7.24 , and $\mathrm{P}_{\mathrm{aCO}_{2}}$ increased from $48 \mathrm{~mm} \mathrm{Hg}$ to $71 \mathrm{~mm} \mathrm{Hg}$. Over the next 24 hours we again cooled him to $35.7^{\circ} \mathrm{C}$, and his $\mathrm{pH}$ increased to 7.43 and $\mathrm{P}_{\mathrm{aCO}_{2}}$ decreased to $40 \mathrm{~mm} \mathrm{Hg}$. We made no ventilation changes during this period.

Because of worsening hypoxemia, despite paralysis and lung-protective ventilation, we initiated inhaled nitric oxide therapy and his oxygenation dramatically improved. We transitioned to inhaled prostaglandin, and then to an oral phosphodiesterase inhibitor. He was eventually extubated and discharged from the hospital.

\section{Discussion}

We hypothesize that hypothermia and paralysis allowed us to use a very low $\mathrm{V}_{\mathrm{T}}$ and a low plateau pressure by decreasing the metabolic rate and carbon dioxide production and thus preventing a substantial $\mathrm{P}_{\mathrm{aCO}}$ increase and acidosis. While it is likely that an even lower $\mathrm{V}_{\mathrm{T}}$ could be achieved with a greater degree of hypothermia, our target was very mild hypothermia of $35-36^{\circ} \mathrm{C}$, in order to avoid the complications of hypothermia, which include higher infection rate and coagulopathy. We believe that even very mild hypothermia reduces the metabolic rate enough to achieve low- $\mathrm{V}_{\mathrm{T}}$ ventilation. Our patient's acidosis was relatively mild $(\mathrm{pH} 7.31)$ and was well tolerated on a $\mathrm{V}_{\mathrm{T}}$ of $4 \mathrm{~mL} / \mathrm{kg}$ ideal body weight. It would be interesting to further investigate mild hypothermia as a means of achieving low- $\mathrm{V}_{\mathrm{T}}$ ventilation and lower plateau pressure in patients with severe ARDS.

While our approach in this patient was to minimize $\mathrm{CO}_{2}$ production, other authors have proposed unconventional methods to improve $\mathrm{CO}_{2}$ removal, such as decreasing airways dead space. In a laboratory study in sheep, Rossi et al developed a modified method of transtracheal gas insufflation that they called intratracheal pulmonary ventilation. ${ }^{6}$ A continuous flow of fresh gas is delivered at the

Table 1. Body Temperature, Tidal Volume, Gas Exchange, and Airway Pressure in a Patient With ARDS

\begin{tabular}{|c|c|c|c|c|c|c|c|}
\hline Temperature $\left({ }^{\circ} \mathrm{C}\right)$ & $\begin{array}{c}\mathrm{V}_{\mathrm{T}} \\
(\mathrm{mL})\end{array}$ & $\begin{array}{c}\mathrm{V}_{\mathrm{T}} \\
(\mathrm{mL} / \mathrm{kg})\end{array}$ & $\mathrm{pH}$ & $\begin{array}{c}\mathrm{P}_{\mathrm{aCO}_{2}} \\
(\mathrm{~mm} \mathrm{Hg})\end{array}$ & $\frac{\mathrm{P}_{\mathrm{aO}_{2}}}{(\mathrm{~mm} \mathrm{Hg})}$ & $\begin{array}{c}\text { Peak Airway } \\
\text { Pressure } \\
\left(\mathrm{cm} \mathrm{H}_{2} \mathrm{O}\right)\end{array}$ & $\begin{array}{c}\text { Plateau Airway } \\
\text { Pressure } \\
\left(\mathrm{cm} \mathrm{H}_{2} \mathrm{O}\right)\end{array}$ \\
\hline 38.0 & 394 & 6 & 7.36 & 58 & 64 & 25 & 23 \\
\hline 38.4 & 351 & 6 & 7.41 & 51 & 80 & 23 & 21 \\
\hline 36.0 & 354 & 6 & 7.42 & 50 & 74 & 23 & 21 \\
\hline 36.0 & 340 & 6 & 7.36 & 62 & 68 & 23 & 21 \\
\hline 35.5 & 296 & 5 & 7.37 & 57 & 61 & 24 & 22 \\
\hline 35.5 & 238 & 4 & 7.31 & 68 & 72 & 20 & 18 \\
\hline
\end{tabular}




\section{Use of Hypothermia to Allow Low Low-Tidal-Volume Ventilation in a Patient With ARdS}

carina, so the upper-airways dead space is bypassed. In healthy sheep, intratracheal pulmonary ventilation allowed lowering $\mathrm{V}_{\mathrm{T}}$ to as low as $1 \mathrm{~mL} / \mathrm{kg}$ while maintaining normocapnia. Similarly, during continuous apneic ventilation, oxygen is usually delivered at the carina while maintaining a stable level of hypercapnia. ${ }^{7}$

A different and fascinating method of removing $\mathrm{CO}_{2}$ is artificial blood filtration. Gattinoni et al used venovenous extracorporeal membrane oxygenation to remove most of the metabolic carbon dioxide in ARDS patients. ${ }^{8}$ More recently, Cressoni et al, in a sheep model, found that half of metabolic $\mathrm{CO}_{2}$ production could be removed with a commercial hemofilter and a replacement solution containing sodium hydroxide. ${ }^{9}$

Both approaches (lowering $\mathrm{CO}_{2}$ production and increasing $\mathrm{CO}_{2}$ removal) may permit low- $\mathrm{V}_{\mathrm{T}}$ ventilation and thus decrease the risk of lung injury. In a paralyzed patient, inducing hypothermia to $35-36^{\circ} \mathrm{C}$ is a safe and low-risk strategy that can be a useful adjunct to other strategies for managing ARDS.

\section{REFERENCES}

1. Slutsky AS. Neuromuscular blocking agents in ARDS. N Engl J Med 2010;16:363(12):1176-1180.
2. National Institutes of Health, National Heart, Lung, and Blood Institute, ARDS Network. Ventilation with lower tidal volumes as compared with traditional tidal volumes for acute lung injury and the acute respiratory. N Engl J Med 2000;342(18):1301-1308.

3. Papazian L, Forel JM, Gacouin A, Penot-Ragon C, Perrin G, Loundou A, et al. Neuromuscular blockers in early acute respiratory distress syndrome. N Engl J Med 2010;16:363(12):1107-1116.

4. Villar J, Slutsky AS. Effects of induced hypothermia in patients with septic adult respiratory distress syndrome. Resuscitation 1993;26(2): 183-192.

5. Wetterberg T, Steen S. Combined use of hypothermia and buffering in the treatment of critical respiratory failure. Acta Anaesthesiol Scand 1992;36(5):490-492.

6. Rossi N, Kolobow T, Aprigliano M, Tsuno K, Giacomini M. Intratracheal pulmonary ventilation at low airway pressures in a ventilator-induced model of acute respiratory failure improves lung function and survival. Chest 1998;114(4):1147-1157.

7. Hess DR, Gillette MA. Tracheal gas insufflation and related techniques to introduce gas flow into the trachea. Respir Care 2001; 46(2):119-129.

8. Gattinoni L, Pesenti A, Mascheroni D, Marcolin R, Fumagalli R, Rossi $\mathrm{F}$, et al. Low-frequency positive-pressure ventilation with extracorporeal $\mathrm{CO}_{2}$ removal in severe acute respiratory failure. JAMA 1986;15:256(7):881-886.

9. Cressoni M, Zanella A, Epp M, Corti I, Patroniti N, Kolobow T, Pesenti A. Decreasing pulmonary ventilation through bicarbonate ultrafiltration: an experimental study. Crit Care Med 2009;37(9): 2612-2618. 